\title{
How to Read Heresy in the Ottoman World
}

\author{
Nir Shafir
}

The topic of heresy is still rarely discussed by historians of the early modern Middle East. There remains a lingering belief that the Ottoman Empire was a particularly tolerant corner of the Mediterranean, at a remove from the sectarian struggles that characterized early modern Europe, a place in which religion only intruded upon the secular sphere of politics proper during certain paroxysms of extremism. ${ }^{1}$ However, the growing literature on the Sunnitization of the empire readily shows that this presumption no longer holds true. ${ }^{2}$ As adherence to Sunnism was equated with political loyalty, heresy became a central concept in shaping the Ottoman body politic. Yet, constructing a concept of heresy for practical and theoretical usage in the Ottoman Empire was not a straightforward matter. ${ }^{3}$ The confessional identity of the empire's subjects had been of minor concern to Ottoman rulers before the ninth/fifteenth century; in the words of Cemal Kafadar, there reigned a "metadoxy," a state of confessional ambiguity in which neither orthodoxy nor heterodoxy was ever fully articulated. ${ }^{4}$ While there were occasional prosecutions of heresy in the ninth/fifteenth century by the Ottoman government, only with the rebellions of the Kuzılbaş followers of Shah Ismāīll in the early tenth/sixteenth century did this state of affairs come to be seriously challenged. In their rush to respond, Ottoman scholars aligned with the government rummaged through their conceptual toolkit to develop a working definition of heresy. ${ }^{5}$

1 The belief in Ottoman tolerance is often an implicit tenet of earlier scholarship, but it is explicitly stated in works like Barkey, Islam and toleration. There are comparatively more works on the upsurge of "extremism" in the eleventh/seventeenth century. See Zilfi, The politics of piety; Baer, Honored by the glory of Islam; Curry, The transformation of Muslim mystical thought 79 .

2 See, for example, Krstić, Contested conversions; Terzioğlu, How to conceptualize Ottoman Sunnitization; Terzioğlu, Where 'ilm-i hăal meets catechism.

3 Readers should note that a number of different concepts—kufr, bid'a, ilhād, zandaqa, ghu$l \bar{u} w w$, etc.-fall under the rubric of "heresy" today. Ottoman authors both distinguished between these concepts and used them synonymously on different occasions. For the sake of clarity, I have tried to point out the original usages throughout this piece.

4 On metadoxy, see Kafadar, Between two worlds 76 . For an application of this concept to the question of 'Alid loyalty before the tenth/sixteenth century, see Ylldırım, Sunni orthodox vs Shi'ite heterodox?; Yllmaz, Caliphate redefined 256-257.

5 Terzioğlu warns us not to take Kafadar's concept of metadoxy to the extreme and points to

(C) NIR SHAFIR, 2021 | DOI:10.1163/9789004440296_007

This is an open access chapter distributed under the terms of the CC BY-NC-ND 4.o license. 
One particular theological (rather than juridical) tool they turned to was heresiography. ${ }^{6}$ At the heart of this medieval genre - often referred to as "religions and sects" (al-milalwa-l-nihal) - was the question of how to understand difference within Islam. Nearly all the texts started with the notion, recalled from a famous hadith, that the Jews were divided into 71 sects, the Christians into 72 , and the Muslims into 73 . The heresiographer's task was to identify the 72 wayward sects destined to burn in hellfire in order to distinguish the one correct path of Islam. ${ }^{7}$

I begin this paper by demonstrating how, after a relative silence of centuries, scholars affiliated with the government in the tenth/sixteenth-century Ottoman Empire refurbished the conceptual tool of heresiography in response to the Kizllbaş and the first war with the Safavids. The article's main focus, however, is on the genre's popular florescence during a second wave of heresiographies that began in the eleventh/seventeenth century when four scholars writing independently of one another between 1024/1615 and 1050/1640 reworked medieval Arabic heresiographies into Turkish texts. Although these heresiographies were initially spurred by the Ottoman-Safavid wars at the time, they quickly transcended the original object of their critique - the Safavidsand began to be used to discuss heresy among the empire's own Muslim population, as myriad readers, scribes, and students in the eleventh/seventeenth and twelfth/eighteenth centuries readily copied, read, and annotated these works. One was even transcribed into Judeo-Turkish and separately translated into Italian, making its way into France and the Dutch Republic by the mideleventh/seventeenth century. ${ }^{8}$ By the end of the eleventh/seventeenth century, heresiographies could function as larger statements about the division of the world along lines of confession, in which a true Sunni core was under direct and indirect assault by its enemies.

occasional moments of strong confessional boundary making prior to the tenth/sixteenth century. Terzioğlu, How to conceptualize Ottoman Sunnitization 308-311. On the rise of a definition of heresy and apostasy in response to Safavid pressures, see Eberhard, Osmanische Polemik; Üstün, Heresy and legitimacy; Ocak, Osmanlı toplumunda zındıklar; Al-Tikriti, Kalam in the service.

6 The juridical and theological bases of heresy are not always so easily distinguished on the ground, but for a good discussion of changes to the juridical notion of heresy and its application, see Burak, Faith, law and empire.

7 On the many usages and variations of this hadith, see Mottahedeh, Pluralism.

8 A heresiography was even integrated into the seventeeth-century English diplomat Paul Rycaut's description of the Ottoman Empire. He recognizes that the heresiography deals only with earlier sects, and supplements the list with newer sects in the empire, many of which are Sufi orders. See Rycaut, The Present State of the Ottoman Empire 300-350. 
If heresiography was a tool meant to reinvigorate the concept of heresy in the Ottoman Empire, then it was a tool with mysterious mechanisms. While one might expect these works to be field guides to new heretical acts or sects emerging in the Ottoman lands, this is not the case. Smoking tobacco or declaring oneself to belong to the "religion of Abraham," to name two acts that elicited accusations of heresy in the eleventh/seventeenth century, never found their way into the descriptions of the 72 errant sects. ${ }^{9}$ Even the Kızllbaş, whose rebellion was largely responsible for rejuvenating the discourse of heresy, were missing from the list. The authors did not even directly associate tenth/sixteenthor eleventh/seventeenth-century groups with medieval heresies. Instead they listed all the obscure groups from the medieval period, long gone by the time of the Ottomans, and used the historical heresies to occasionally draw indirect connections with the present. Medieval authors had written heresiographies to highlight the verity of their particular branch of theology at the expense of their competitors, but what function did such fixed texts serve centuries later?

A similar problem arises in the study of Islamic law when scholars try to conceptualize the connection between the abstracted, decontextualized, and atemporal world of doctrinal and jurisprudential works and the very specific and locally grounded world of court records. In an attempt to formulate Islamic law as a unified textual "formation," Brinkley Messick has labeled these two worlds the "archive" and the "library," respectively. The archive (i.e., the court records) contains texts with particular details such as names and places, whereas the library (i.e., legal opinions like fatwas) is purposefully anonymized and abstracted. The archive is contingent and local, while the library is cosmopolitan and universal. ${ }^{10}$ Heresiographies then might be considered part of the atemporal and universalized "library" due to their continued application of the basic divisions of heretical sects established centuries beforehand to Ottoman social reality. Yet, if the heresiographies comprise the library, what then might the archive be? How might we localize these texts to tell the story of Sunnitization in the early modern Ottoman Empire?

$\underline{Z} i k r$ and tobacco smoking were considered bid'a or "innovations." Ottoman scholars routinely distinguished between bid'a in articles of belief, bid'a in religious rituals and bid'a in social customs; it was bid'a in articles of faith that were held to be the most grievous and amounted to heresy, while $z i k r$ would belong in the second category, and smoking tobacco in the third. 
To understand the full impact of these heresiographies on Ottoman society, we have to turn to the material texts themselves. ${ }^{11}$ Certainly, the traditional tools of philology can provide some of the answers. As I demonstrate in the first half of the article, a close and comparative reading of the heresiographies allows us to see how Ottoman authors emphasized particular sects as a means to affiliate, indirectly, their enemies' beliefs with medieval heresies and to highlight their own form of Sunnism as the most proper path. But this is only half the story. The placement of the heresiographies within miscellanies (Ar. majmū́a / Tr. mecmūa a), their ownership records, and copyist statements across hundreds of copies constitute an equally important source. While art historians and codicologists have engaged in close readings of individual manuscripts, there is now, thanks to the accessibility granted by mass digitization, the possibility to analyze hundreds of manuscripts and therefore develop new methods of interpretation. In this paper, the mass analysis of the manuscripts helps demonstrate how the Ottoman discourse of heresy, which initially targeted the Kızılbaş and Safavids on the edges of empire, shifted its focus to the empire's central cities by the eleventh/seventeenth century. This in turn helps resolve a key impasse in the historiography of confessionalization in the Ottoman Empire, in which the phenomenon is often explained by emphasizing either an external impetus of the Safavids/Kızlbaş or an internal system of disciplining Muslim religious practice. ${ }^{12}$ The connection between these two poles is more often suggested than demonstrated, however. I argue that looking at the larger manuscript record, that is, the works copied alongside these heresiographies, reveals the conceptual traffic between the two poles.

My hope is that the secondary contribution of this essay is to develop and demonstrate a few techniques of a relatively new methodology based on the mass reading of manuscripts from the early modern Islamic world. ${ }^{13}$ Take, for

11 The "archival" life of heresy in general can occasionally be found in the register of official orders dispatched (i.e., mühimme defterleri) or even in its official legal opinions (fatwas), such as the one by Ebü's-su'ūd I touch upon later, as the government experimented with a vocabulary to define heresy. None of these, though, actively use the terminology of the heresiographies and so the question of the relationship of these texts to Ottoman social reality remains.

12 See for the example the introductory discussion in Terzioğlu, How to conceptualize Ottoman Sunnitization; Atçıl, The Safavid threat. On the general application of the term confessionalization, a term from European historiography, to the Ottoman context, see Krstić, Contested conversions.

13 I developed some of my ideas on the impact of mass reading in Gratien, Polczyński and Shafir, Digital frontiers of Ottoman studies. There is a new movement to use manuscript 
example, our notion of reception. It currently relies on the crude metric of "popularity," in which a tally of extant manuscripts translates to the supposed reach of a text. But there is much more that can be done, and what follows is an experiment in interpreting the manuscript record. These material clues within manuscripts are the very "archive" of the heresiographies, evidence that allows us to situate them within the social life of the empire and change our interpretation of the texts themselves.

\section{$2 \quad$ Medieval Visions}

An Ottoman heresiography is built upon a rather spare skeleton. The author voices a desire to find the difference between Sunnism and deviant and wayward branches of Islam. The aforementioned hadith regarding the inevitable division of the Muslim community into 73 sects - a vestige of the many traumatic civil wars of the early Muslim community ${ }^{14}$-is invoked before the author delves into his particular list. These are divided into five or six main groupings, each of which is given a chapter. The main three are Mu'tazilis, Shi'is, and Kharijites, which are almost always followed by theological branches or divisions from the third/ninth or fourth/tenth centuries, such as the Jabriyya, Najjāriyya, and Murji'a. Upon this skeleton, authors can flesh out their text according to the amount of detail they devote to each sect-which is often simply an eponymous statement that "the 'So-and-so-iyya' are the followers of 'so-and-so'" - and the description and possible refutation of their heresy. Authors differentiate their text by the particular groups they place under each heading, which seem to differ in particular with the more marginal groups. This shared framework explains why these texts often were simply referred to by generic titles in mecmū'as, bookstores, and libraries such as "Religions and sects" (al-milalwa-l-niḩal), "Explaining different sects" (Bayān al-madhāhib almukhtalifa), "Explaining deviant sects" (Bayān al-firaq al-ḍälla), or "Explaining the difference of religions" (Bayān ikhtiläf al-milal). Finally, in the Ottoman period, these heresiographies nearly always contained an initial or final chapter that established the proper Sunni creed.

The medieval heresiographies from which the Ottoman heresiographies drew were a byproduct of divisive debates over the nature of the Muslim community in its early centuries. Differences over issues like who belonged to the

marginalia as documentary sources. See Görke and Hirschler, Manuscript notes, and the special issue (9:2-3) of the Journal of Islamic manuscripts from 2018.

Van Ess, Der Eine i, 7-82. 
community, who should lead it, and what religious powers they possessed gave rise to differing theological and political stances that eventually solidified into discrete groups, such Kharijites and Shi'ites. At the same time, the fluorescence of rational theology (kaläm) in the medieval period, especially following the introduction of the tools of Greek philosophy, introduced new intellectual questions. Groups like the Mu'tazilites held theological positions that ran counter to those of the hadith people, and thus opened another rift in the Muslim community. ${ }^{15}$ Furthermore, the students of rational theology would adopt their teachers' arguments and then try to develop their own, casting all those who disagreed with them as infidels. As a consequence, multiplying branches and subbranches of theology emerged, each of which regarded the others as heretical and wrote heresiographies to make their point. ${ }^{16}$ The divisive intellectual environment came to a close in the "Sunni revival" of the fifth/eleventh and sixth/twelfth centuries with the rise of the much more inclusive Ash'ari and Maturidi theological schools that set higher standards for denouncing and anathematizing intellectual rivals. ${ }^{17}$

If we look today at the remaining manuscript copies of these medieval heresiographies, we would find the most popular one to be Religions and sects (almilal wa-l-nịal) by Muhammad b. 'Abd al-Karīm al-Shahrastānī (d. 548/1153). Like all heresiographies, it starts with a rendition of an apocryphal hadith stating that "my community will divide itself into 73 divisions and only one will be saved." Unlike other heresiographers, though, Shahrastānī was remarkably latitudinarian in his descriptions of the history and stances of each theological school, refusing to dismiss and anathematize any one sect, and instead organized the divisions according to their views on central theological questions. ${ }^{18}$ Writing in the irenic era, his ecumenism extended even to descriptions of non-Muslim unbelief: Jewish and Christian sects, Indian religions, and various ancient Greek philosophical schools were described in detail, though perhaps with less interest than the Muslim sects. ${ }^{19}$ For this reason, the text has achieved some fame among Orientalists of the nineteenth and twentieth centuries as a pioneering work of comparative religion by a medieval Muslim scholar, a doxography rather than a heresiography. ${ }^{20}$ The heresiographical tra-

\footnotetext{
15 A basic version of this story along with its relation to the question of heresy can be found in van Ess, The flowering.

16 El-Shamsy, The social construction 105-106.

17 El-Shamsy 106. For information on the Sunni revival in general, see Berkey, The formation of Islam 189-202.

18 Knysh, "Orthodoxy" and "heresy" 50-51; Sourdel, La classification des sectes.

19 Lawrence, Shahrastānī on the Indian religions; Shahrastānī, Livre des religions.

Wasserstrom, Islamicate history of religions?
} 
dition in Shahrastāni’s hands was less a call for the persecution of the infidels and heretics of the sixth/twelfth century than a clear expression of the modus vivendi that marked the new Sunni consensus.

Yet, it would be a mistake to assume that Shahrastānīs work, or really any other heresiography, was commonly read in Anatolia before the tenth/sixteenth century. The IslamAnatolia database of 7,000 texts written in medieval Anatolia finds no easily identifiable heresiography, for example. ${ }^{21}$ When we look at the extant copies of Shahrastānī's text in Istanbul's libraries today, we find that the dated copies are nearly all from the sixth/twelfth and seventh/thirteenth centuries, following its release, and from the mid-eleventh/seventeenth century onward. ${ }^{22}$ We do not find, however, many copies made during the ninth/fifteenth and tenth/sixteenth centuries, the foundational moment for the development of an Ottoman concept of heresy. ${ }^{23}$ As I will suggest below, the urge to collect and copy the heresiographies of Shahrastānī and other medieval authors was likely a response to the heresiography's popularity in the eleventh/seventeenth century. In other words, there was little demand on the part of Ottoman readers for these older heresiographies before this time.

21 IslamAnatolia: The Islamisation of Anatolia, c. 1100-1500, available at: https://www.islam -anatolia.ac.uk/?page_id=333 (last accessed: 30 June 2018). Unfortunately, the database only contains mecmū'as that were copied in Anatolia, not books made in individual volumes. While there is one short work on the Qalandars written in the period, it does not follow the heresiography genre itself. De Nicola, The Fusțāt al-'adāla.

22 Of the twenty or so copies of Shahrastānī’s al-Milal wa-l-nihal in Arabic in the Süleymaniye Library (Süleymaniye Kütüphanesi; hereafter sk) and Millet Library today, about 16 are dateable. For the old copies, often collected in the twelfth/eighteenth century, see Millet Kütüphanesi, Ms Feyzullah Efendi 1175 (copied in 589/1193); Ms Feyzullah Efendi 1176 (copied in 629/1231-1232); SK, MS Laleli 2443 (written in 59o/1193-1194); MS Fatih 3151 (copied in 593/1196-1197); MS Serez 1242 (copied in 595/1198-1199); MS Sehid Ali Pasa 1731 (written in 9 Jumadi I 596/26 Feb 1200); MS Turhan Valide Sultan 202 (copied in 613/12161217); Ms Ayasofya 2369 (copied in 620/1223-1224); Ms Laleli 2444 (written in 627/12291230); Harput MS 398 (copied in 729/1328-1329); Ms Ayasofya 2370 (copied in 734/13331334). There do not seem to be any major commentaries or extensions of Shahrastani's work with the exception of the obscure and short piece to be found in the Topkapı Palace library. See the first volume of Ghayāt al-afkār wa nihāyet al-anzz̄àr, Topkapı Sarayı Müzesi Kütüphanesi, Ms Ahmed III 1868. The other medieval heresiographies, like Ibn Ḥazm's, seem to follow the same pattern but with far fewer copies.

23 Only one extant copy, SK, Ms Fatih $315^{2}$ is from the beginning of the tenth/sixteenth century (1 Muharram 907/17 July 1501), but the ownership statements suggest that it was originally owned by a man from Shirvan in Azerbaijan and made its way to Istanbul in the mid-eleventh/seventeenth century, where it was eventually owned by the primary imam of the Sultanahmet Mosque. 
During the medieval period, the notion of the " 72 sects" retained its significance, not as a list of specific heresies but as a generic marker of the stark line between belief and unbelief. We can see this in its frequent use as a trope in the poetry of medieval poets from Anatolia. The Anatolian poet-mystic Yūnus Emre (d. c. $720 / 1320$ ), for example, states that a seeker on the path needs to subject himself and pay homage to the 72 sects (yitmiş iki millet) before transcending them to achieving divine unity. ${ }^{24}$ Jalāl al-Dīn al-Rūmī (d. 627/1273) likewise used the figure frequently. ${ }^{25}$ Whereas in the Bektashi initiation ceremony, a guide would instruct seekers that they were slaves of the Twelve Imams, part of the saved group (gürüh or firka-i nāciye), and separated from the 72 sects. $^{26}$

The learned in the Ottoman Empire certainly knew about heresiographies before the tenth/sixteenth century, but they likely read them as geographies, a means of describing and dividing the world. The catalog of the palace library of the Ottomans during the reign of Bāyezīd II (886-918/1481-1512) reveals valuable clues as to its reception in the years immediately prior to the Kızllbas and Safavid challenge that would change the usage of the heresiographies. The catalog lists five copies of an unspecified heresiography, listed simply by its generic title as al-milal wa-l-nihal, some of which were likely to be Shahrastān's text. ${ }^{27}$ What is surprising, though, is not the texts' presence in the library but their classification. They were grouped not under the heading of theology (kalām), as we might assume, or even law ( $f i q h)$, but under the capacious heading of history, which included not only chronicles but also stories of the Prophet, descriptions of wonders, and manuals on statesmanship, war etiquette, horsemanship, and falconry. ${ }^{28}$ The cataloger lists the heresiographies after al-Birūnī's (d. c. 440/1048) descriptions of India and before the section on horsemanship and wonders, and the entry has a statement describing the heresiographies specifically as histories (min qabli tawärikh). The library's classification suggests that the heresiographies were read more as books of curiosities and marvels that revealed what madmen lived in the distant corners of the past than guides to

\footnotetext{
24 Yūnus Emre, Yûnus Emre Dîvânı ii, 51, 133, 148, 16o, 187, 358, 371, 381, 387, 389.

25 Mottahedeh, Pluralism.

26 Birge, The Bektashi order 193; following the citation in van Ess, Der Eine i, 3.

27 For the catalog, see Academy of Sciences of Hungary, Ms Török F. 59, 193. One undated manuscript of Shahrastānī's al-Milal wa-l-niḩal bears the almond-shaped stamp of Bāyezīd II's library in Sk, Ms Turhan Valide Sultan 201.

28 There were no other recognizable heresiographies in these sections. Al-Ghazāli’s Tafriqa bayn al-zandaqa wa-l-imān, which discusses the nature of heresy, was found in the section on theology and an unknown Alfäz al-kufr was placed under law, but neither are heresiographies. Academy of Sciences of Hungary, MS Török F. 59, 63, 97.
} 
contemporary theological heresies. When the Ottoman government revived the genre, though, they would turn it into a theological weapon.

\section{Reviving Heresy in the Tenth/Sixteenth Century}

At the beginning of the tenth/sixteenth century, the Ottoman establishment did not possess a particularly sectarian mindset, but, in just a few decades' time, government-affiliated scholars revivified the concept of heresy and with it the genre of heresiography. The sudden rise of the Safavids-a minor Sufi family in Ardabil that managed to cobble together a diverse set of followers, including many nomadic Ottoman subjects, into a formidable political and military machine—-spurred scholars like Kemālpaşazāde (d. 940/1534), Lüții Pasha (d. 970/1563), and Ebū's-su'ūd (d. 982/1574) to utilize and even author heresiographies. Together, they represent a concerted effort to define the basis of Ottoman Sunnism through their legal rulings, catechisms, and heresiographies. ${ }^{29}$

When these authors sought inspiration for their works, though, it seems they turned to a different tradition of heresiography, that of Eastern Hanafi authors from fourth/tenth- and fifth/eleventh-century Transoxiana, like Makhūl alNasafí (d. 317/930), rather than referring to the more well-known works of Shahrastānī and Ibn Ḥazm (d. 456/1064) found in their libraries. ${ }^{30}$ These Eastern Hanafi heresiographies, as Keith Lewinstein has argued, "look confused and superficial" compared to the more detailed Ash'ari and Mu'tazili exemplars of the genre because they cursorily dismiss other sects to define Hanafi Sunnism as the most correct path. ${ }^{31}$ Kemālpaşazāde and Lüțì Pasha's texts share some of the defining features of the Eastern Hanafi heresiographies, such as the inclusion of the Küziyya and Shimräkhiyya groups and a tendency to label all theological branches with the suffix "iyya." ${ }^{32}$ The most likely source text was an early sixth/twelfth-century book by a certain 'Uthmān b. 'Abdallāh b. al-Irāqī al-Ḥanafī titled al-Firaq al-muftariqa bayn ahl al-zaygh wa-l-zandaqa (Separating sects among the deviants and heretics). ${ }^{33}$ Ottoman

29 Krstić, From shahāda to caqīda; Krstić, State and religion; Üstün, Heresy and legitimacy.

3o The Ottomans, like the Seljuks before them, often turned to Eastern Hanafi authors for inspiration in building a new concept of Hanafi Sunnism. See, for example, Aykan, A legal concept in motion; Rudolph, Al-Mãturìdī.

31 Lewinstein, Eastern Ḥanafite heresiography; Tan, Hanefî-Mâturîdî firak geleneği.

32 Lewinstein, Eastern Ḥanafite heresiography 587, 590-591; Tan, Geç dönem Hanefî-Mâturîlî firak geleneği 184-186.

33 Many of these Eastern Hanafi texts exist only in single copies today, so it is difficult to track 
authors perhaps drew from this Eastern Hanafi source because it more readily allowed them to declare their political enemies heretics: it championed a particularly Hanafi Sunnism while also dismantling the latitudinarian views of the Sunni consensus that had held sway in the past. After all, copies of Shahrastānì's texts in the palace library were listed under the rubric of history rather than theology, and a different type of text was needed to paint a bright portrait of Ottoman Sunnism against the darkness of past heresies.

Lüțî Pasha's heresiography uses his list of 72 sects to expand upon the ten qualities he thinks that Sunnis must possess. ${ }^{34}$ The first quality is the requirement to pray five times a day in a congregation (about which see the paper by H. Evren Sünnetçioğlu in this volume), the third quality is to not raise a sword against the sultan, the fourth is to not express doubts about faith, and the seventh is to not debate or argue in religious places. ${ }^{35} \mathrm{He}$ then finds these qualities, or the lack thereof, in his description of the deviant sects. The Magrüriye rejects the Friday prayer while the thirty-fifth sect, the Abbāsiye, raise their swords against the sultan. ${ }^{36}$ These groups no longer existed according to the author: he ends every description with the words "they went astray and were destroyed (azub heläk oldılar)." Even groups like the Shi'ites and the Reväfiz, whom he would presumably deem to have existed, receive this enjoinder. ${ }^{37}$ The past

their reception. Al-'Irāqī's text seems like good fit, though, because of Kemālpaşazāde's inclusion of a number of the same non-Muslim sects. Muzaffer Tan read the inclusion of these non-Muslim sects as a sign that Kemālpaşazāde used another heresiography as a source, but it seems that the sects were lifted directly from al-'Irāqī's work. Lewinstein, Eastern Ḥanafite heresiography 586-587; Tan, Geç dönem Hanefî-Mâturîdî firak geleneği 189-19o; al-'Trāqì's text was published over five decades ago, but the editor of the text, Y. Kutluay, did not provide the accession number of his source. See Hanefi, Sapıklarla dinsizlerin. I found the original copy in Sk, Ms Süleymaniye 791. It was copied by a Alī b. Yāsīn b. Muhammad al-Ṭarābulusī al-Ḥanafî, a scholar of seemingly Arab origins on 9 Shawwal 904/ 20 May 1499. The timing of this only surviving copy fits well with a renewed interest of the Ottoman establishment in heresiographies (i.e., right before the start of Shah Ismāîl's campaigns). Not much is known about the copyist, but his last name suggests that he came from greater Syria. There is a collection of fatwas from him in Beyazit Devlet Kütüphanesi, Ms Veliyüddin 1587 .

34 Lüțî Pasha, Risāle-i Fırak-i ḍălle, sk, Ms Ayasofya 2195. Parts of this text, such as the list of ten qualities, are found in his other works. The heresiography also appears under the title Hayāt-i ebedī. On his role in the Sunnitization process, see Krstić, A catechizing grand vizier.

Lütfi Pasha, Risāle 110a-b.

36 Ibid. 115 b.

37 The only exception to this is the Wāsiliyya, the initial Mu'tazilis, from whom Ibn Ash'ar first emerges only to reject them and become a Sunni again. Also, Lüṭ̂i Pasha does not equate the Shi'ites and the Revāfiz as the other heresiographers do. Lüții Pasha, Risāle 112b. 
becomes a means for Lüțî Pasha to indirectly reference the Kızlbaş rebellion in his portrayal of Sunnism: true Sunnis do not rebel, spiritually or politically.

Kemālpaşazāde's short treatise, only a few folios long and probably written between $915-930 / 1510-1530$, follows the same approach and begins simply as a list of heresies sans introduction. The first part covers heresies deemed completely outside Islam, like Jews, Brahmins (barāhima), philosophers, star worshippers (najamiyya), reincarnationists (ahl al-tanāsukh), the Bäținiyya, and the "worshippers of the cow's head" ('abadat ru'üs al-baqar). The point of this initial section is to cast sects like the Bătiniyya, which were formally Muslim, outside the circle of Islam. One cannot accept the jizya (poll tax imposed on non-Muslims) from these heretics nor can one accept their ritually slaughtered meat or marry their women. Killing them is like killing an apostate, an act that elicits neither punishment nor blood payment. In other words, these heretics are not to be afforded even the traditional rights of protected non-Muslims. The second part focuses more on the errant sects within the fold of Islam, which he quickly sketches, often only with a name and a sentence. ${ }^{38}$ The sentence or two of description comes across as an attempt to define the Sunnism in the negative. For example, the Mushabbihah allow for the killing of opposing Muslims, marrying sisters and daughters, and drinking wine. ${ }^{39}$ Other descriptions, like that of the Khattābiyya, read as a thinly veiled attack on the Shi'ites (rawäfid) and the Kızlbaş: they believe that Jacfār al-Ṣādiq, al-Khaț̣āb, and even 'Alī are gods. ${ }^{40}$

Only at the end does Kemālpaşazāde provide more specific instructions by repeatedly stating that "the sultan must call on all [these heretics] to repent or kill them." Yet, he leaves a chance for heretics to enter the fold again and for this reason, he asserts that, if they repent, they must not be barred from mosques and can be buried in Muslim cemeteries, save for the Bātiniyya and Hulüliyya, who are to be treated unequivocally as apostates, "whether they repent or are killed." ${ }^{41}$ Who are these two sects beyond the pale? He gives no information about them whatsoever, other than calling on the sultan to force the Hulüliyya in particular to repent and the Bătiniyya being "the most evil of all of them and

38 Kemālpaşazāde's descriptions are so cursory that some readers filled in the margins with more information on each sect.

39 Kemālpaşazāde, Risāla, sK, Ms Reşid Efendi 1031, 279b.

40 Ibid.

41 To prove the point, he quotes the jurist Mālik that zanādiqa and Bātiniyya should not be allowed to repent after being captured. Kemālpaşazāde, Risāla 28ob. For an overview of jurists' opinions on when a heretic should not be offered a chance to repent see Griffel, Apostasy. 
the most heretical."42 Their names, however, can give us a sense of what Kemālpaşazāde found so repugnant. Hulüliyya suggests a belief that God incarnates within particular leaders, an indirect reference to Shah Ismāîl's Kızılbaş followers, who considered him an infallible god. In anti-Safavid treatises, the connection was often explicitly stated: Ḥüseyin b. 'Abdullāh el-Şirvānī, a proOttoman polemicist fleeing from the Safavids, argued that the Kızlbaş worshiped Safavid leaders as deities. ${ }^{43}$ The second sect, the Băținiyya, might refer to groups accused of denying the literal meaning of sacred texts, and thus their moral exhortations and ritual prescriptions, in favor of esoteric interpretations. ${ }^{44}$ This was a common refrain about sects like the Isma'ilis centuries beforehand, but it gained new importance in the tenth/sixteenth-century Ottoman Empire, where many antinomian dervish groups had turned Kızllbaş.

The emphasis on these two accusations-attributing divinity to leaders and antinomian esotericism - is what ultimately distinguishes Ottoman heresiographies from their medieval predecessors. First voiced by Kemālpaşazāde, the claim is repeated in all the heresiographies and reflects a particularly Ottoman usage of the genre. To underline the fact these heresies were alive and well, he states that the rule of the Bākiya in Azerbaijan is Bătiniyya rule (whereas the cow-worshippers are in Herat). The location of these groups makes it clear that heresy is found outside the empire, among its enemies, rather than within its own population. Later, he states, "if there exists in the land a ruler from the Ghäliba or the Qadriyya or the Khawärij or the Juhmiyya or the Najjäriyya or the Mujassima, then their rulings are invalid."45 This statement serves to define the empire as Sunni and run in partnership with legal scholars, a point he underlines after repeating some basic theological tenets of Sunnism, declaring that "whoever has this as his religion and belief, then he is a Sunni, and whoever is against anything from it, then he is a heretic [lit. innovator $\left(\right.$ mubtadic $\left.^{c}\right)$ and against the Sunnis and jurists." 46

In the tenth/sixteenth century, the aforementioned notion of the 72 sects continued to function as a means of defining the line between heresy and belief, between rebellion and obedience. This is clearly seen in the rulings of the şeyhü'l-islām (chief jurist) Ebü's-su'ūd, who was Kemālpaşazāde's successor and student, regarding the treatment of the pro-Safavid Kızılbaş. The last of the

42 Kemālpaşazāde, Risāla, 278b, 279 b.

43 Yılmaz, H. İran'dan Sünni kaçısı; Yılmaz, Caliphate redefined 261. See also Şirvānī’s comments on the mübăhiye, mentioned later by another, later Şirvānī.

44 Hodgson, Bāținiyya.

45 Kemālpaşazāde, Risāla 281a.

46 Ibid. 
rulings responds to a question whether the war against the Kızlbaş is justified given that they claim to be Shi' ites and testify that "there is no god but God." The inquiry forced Ebü's-su'ūd to examine the nature of their heresy, and he states that they were neither Shi'ites nor even one of the 72 sects destined to burn in hell. The Kızllbaş "take a share of evil and corruption from each of [the 72 sects]. They have added together, according to their whims, whatever heresies and innovations they choose and invented a composite heresy and deviation." ${ }^{m 7} \mathrm{He}$ then goes on to list their heretical actions and beliefs, which include insulting the Quran and the sharia, burning holy books, treating scholars with contempt, worshiping their leaders as gods, and cursing 'A''isha, 'Umar, and, indirectly, the Prophet Muhammad. Here, in Ebū's-su'ūd's ruling that turns a rebellion into a heresy, we find the closest attempt to match the heresiographies to the social realities of the Ottoman Empire. He recalls the heresiographies not to identify the particularities of Kizllbaş belief but to highlight their novelty, which exceeds even the heresies of old as represented by the notion of the 72 sects. The heresiographies serve not as a reference manual but as a generic bank of imagery, a backdrop against which an Ottoman Sunnism would be drawn.

In the works of Kemālpaşazāde and Lüțî Pasha, we find for the first time in centuries a revival of the heresiography tradition. Like their Eastern Hanafi precursors, these heresiographies are rather crude attempts to fashion tools and concepts to fight against the Kızılbaş and the Safavids, and their revival helped dismantle the irenic Sunni consensus that had held sway for so long. They mention no current heresies because their aim was to define an Ottoman Sunnism in the negative and project an image of the world in which a righteous Sunni empire was constantly threatened by unbelievers at its borders.

\section{4}

\section{Heresiographies in the Eleventh/Seventeenth Century}

Less than a century later, a new wave of heresiographical works would seize the attention of Ottoman readers and become the heresiographies predominantly found in manuscript libraries today. The initial Ottoman heresiographies were written by members of the highest echelons of the Ottoman government, generally in Arabic (albeit in a very simple kind), and read and used by a limited group of government officials. The eleventh/seventeenth-century heresiographies, on the other hand, were written by respected but middling scholars who, rather than forging a vision of heresy as state policy, sought jobs and political 
influence by tapping into an already strong current of popular and governmental interest in identifying and eradicating heresy. Sometimes they pushed the government to act even more radically than it had, as we will see in Şirvānī's heresiography below. For this reason, the new generation of heresiographies were all in Turkish, appealing specifically to a popular Rumi (that is, Turkishspeaking) public that read them alongside a variety of other works. The process began with a war and three or four authors who translated and reworked the heresiographies between 1024-1050/1615-40.

The first to be written, and one of the most popular, was the rather blandly titled, A treatise explaining the various sects (Risāle fi beyān mezāhib muhtelife $).{ }^{48}$ It was penned circa 1024/1615 by the prolific scholar Muhammed Emin b. Șaḍre'd-dīn Mollazāde el-Şirvānī (d. 1036/1627), a refugee fleeing the brutal Safavid persecution of Sunnis in the Caucasus who became a professor (mudarris) in a number of cities around the Ottoman Empire, including Aleppo, Istanbul, Mecca, and Bursa. ${ }^{49} \mathrm{He}$ likely met his particularly receptive patron, the grand vizier Mehmed Pasha, in the first of these cities when he served as a mudarris there in 1024-1025/1615-6. ${ }^{50}$ His Mehmed Pasha was most likely (Dāmād) Öküz Mehmed Pasha (r. 1023-1025/1614-6, 1028/1619), ${ }^{51}$ who served two terms as grand vizier under Aḥmed I and 'Oșmān II and launched a renewed campaign against the Safavids from Aleppo in the spring of 1025/1616 after spending the previous year making preparations in the city.

We should not discount the impetus provided by the second and third set of Ottoman-Safavid Wars (1012-1027/16o3-18 and 1032-1049/1623-39) for these heresiographies. Scholars have traditionally focused on the initial battles between Sultan Selīm I (918-926/1512-1520) and Shah Ismāîil I (9o7-93o/15o1-

48 A critical edition of the treatise was published in el-Şirvānī, Tercümânü'l-ümem. Fiğlalı, the editor, gave it the title Tercümânü'l-Ümem based on a title found in one of the manuscripts, though this does not seem to be a common title for it. Fuğlalı provides a Turkish translation in a subsequent article, İbn Sadru'd-Din eş-Şirvânî; van Ess claims that this work has an Arabic original, found in SK, MS Laleli 2237, attributed to the author Meḥmed Nūrī Şirvānī. However, a close examination of the work shows that it was copied in $1168 / 175^{-}-175^{1}$, and it is most likely a singular Arabic translation of the piece from the twelfth/eighteenth century, Der Eine ii, 1179-118o.

49 Muhamammad Emīn b. Șadre'd-dīn Mollazāde el-Şirvānī, Risāle fi beyān meżāhib muhtelife, SK, Ms Darülmesnevi 258, 74b. The earliest copy (from 5 Dhi'l-Huja 1025/14 December 1616) I came across can be found in the Austrian National Library, MS NF 13 and 13a. The JudeoTurkish copy apparently dates from 1615 in Aleppo. See, Leiden University Library, Ms Or $1129(\mathrm{~g})$.

50 Altıntaş, Şirvânî, Sadreddinzâde 208-209.

$5^{1}$ On the question of his patron, see also Fığlalı, İbn Sadru'd-Din eş-Şirvânî 251-253. 
1524) in the early tenth/sixteenth century as the main context of sectarian formation. Indeed, these battles did open a space for the heresiographies, as we have seen, but the waves of persecutions that followed the Safavid conquest of the Caucasus under Shah 'Abbās (996-1038/1588-1629) also catalyzed a more extreme form of confessional polarization. ${ }^{52}$ Waves of Sunni scholars from Shirvan and other parts of Azerbaijan arrived in Ottoman cities, often profusely thanking the Ottoman state in their treatises for sheltering them from what they describe as particularly barbarous attacks. ${ }^{53}$

The animus against the Safavids is most clearly seen in the heated conclusion of Şirvānī's heresiography. He calls on the sultan to "appoint to every city in the empire a scholar well-versed in theology ('ilm-i kelām) who knows proper and improper belief so as to protect the creed of Islam from deviant sects and heresies and the like and protect the domains of Islam against its internal enemies, just as the Muslim soldiers and walls preserve it from its external enemies." ${ }^{54}$ After castigating the sultan for disparaging scholars' work and failing to send scholars to the major cities to educate the people, he ends with an interesting comment as to the purpose of heresiographies. He argues that an enemy leader might try to win through intellectual means rather than brute force.

Now, for example, the soldiers of Islam, may God grant them victory, have set out against the Kızılbaş. What were to happen if the Shah of Persia said, "The cause of our enmity is confessional difference (muhälefet- $i$ mezheb). So let the confessions be examined and whatever side the Truth is on, let us all follow that and set aside this fight." Shi'a extremists (gulāt-ı $\operatorname{Reva} f(\dot{z})$ would spread their corrupting doubts regarding the faith and bring the beliefs of the commoners crashing to the ground. It is necessary to defeat the enemy by having an erudite scholar who knows all the

$5^{2}$ See, for example, Dressler, Inventing orthodoxy; Allouche, Ottoman-Safavid conflict; For an overview of the diplomatic developments on this front, see Küpeli, Osmanlt-Safevi münasebetleri.

53 Refugees have been important figures in driving anti-Safavid polemics in the empire. For earlier examples, see Eberhard, Osmanische Polemik 53-6o. Besides Muhammed Emin elŞirvānī, see, for example, Sa'deddīn Şirvānī and Feyżullah Efendi, whose family fled from Karabagh to Erzurum. For an example of treatises dedicated to the Ottomans by refugees, see the first few folios of Nūrallah b. Muhammad Rafī‘a b. 'Abdurrahīm, Risālat al-Shirwān̄̄ ilā muftìzamānihi, Egyptian National Library and Archives, Ms Majāmī‘ Ṭal'at 476, 1a-27b.

54 Şirvānī, Risāle, Ankara Üniversitesi, D.T.C.F. Kütüphanesi, Ismail Saib Sencer Koleksiyonu MS I/3175, 15a-17a (hereafter, Şirvānī, Risāle); sk, Ms Darülmesnevi 258, 83a-84a, Ms Çelebi Abdullah 195, 16a. 
sects' ideas and practices and is aware of their sources and principles so that he can force the enemy to concede with irrefutable evidence. ${ }^{55}$

Şirvānī expresses here both an understanding that the fight with the Safavids is at its heart a confessional battle and a deep fear of any prospect of an "examination of confessions," as any such initiative would be a ruse to infiltrate the empire. His fears were not necessarily misplaced. There actually was a tentative truce between the Ottomans and the Safavids between 1021-1024/1612-5, right when Şirvānī wrote his treatise. And Nadir Shah, upon making peace with the Ottomans in 1149/1736, did eventually propose to make Ja'fari Shi'ism the fifth school of Sunnism. ${ }^{56}$ For this reason, Şirvānī argues that only a scholar trained in theology could confront these heathens in a debate and force them to concede (ilzām) when faced with irrefutable evidence. Şirvānì's point, colored by the current war against the Safavids and his own forced migration, makes it clear that heresiography is meant to help distinguish errant belief among other Muslims and defeat them with proper proof. Moreover, he is increasingly worried about foreign heretics disguising themselves within Ottoman society itself and thus uses the heresiography to push the hesitant Ottoman government to act while conveniently providing a steady occupation for scholars like himself.

Despite Şirvānī locating his work in actual political exigencies, his heresiography, like the others, offers only scattered hints as to its practical application. Comprising about ten to twenty folios, it goes through the usual motions of listing the main sects with a cursory description of their theological beliefs. Like its predecessors, of which he might have had some knowledge, he uses familial resemblances to the historical sects to indirectly attack the enemies of the Ottomans, though with a greater focus perhaps on the Safavids themselves instead of the Kızılbaş rebellion. As mentioned before, Kemālpaşazāde focused on the perfidies of the Battıniye and Hulüliye, and these groups appear in Şirvānīs heresiography as well. The Hulüliye believe that "a person, with practice and effort, can reach a stage in which he becomes one with the true Beloved and obliterates himself in God. God then incarnates in him. Most of the Persian wandering dervishes (ışıklar) are of this belief. ${ }^{\prime 57}$ Once again, the emphasis lies on sects that consider their rulers divine.

55 Şirvānī, Risāle, 8b-9a; 17a; SK, Ms Darülmesnevi 258, 84a, MS Çelebi Abdullah 195, 16a; elŞirvānī, Tercümânü'l-ümem 335 .

$5^{6}$ Tucker, Nadir Shah. See also the essay in this volume by Selim Güngörürler.

57 El-Şirvānī, Tercümânü'l-ümem 328. 
Şirvānī groups the Hulūliye under the special heading of "heretical Sufism" (melāhnidetü'l-Süfiye), which also includes the Mübāhiye, Zenādıka, Kalenderiye, Mürāiye, Müstahdamiye, and Mütáabidiye. Although these groups are relatively unimportant in comparison to Şirvānı̄s general attack on the Safavids, they are rare examples of novel heresiographical categories being introduced. These categories did not come from Ottoman social reality, but neither were they found in Islam's first centuries. In elaborating this new category of heretical Sufism, Şirvānī likely drew on earlier sources. For example, the Mübāhiyea group of the morally apathetic that appears in the end times according to al-Kāshifĩ (910/1504-1505) — was associated with the Kızlbaş in a work by another refugee from Shirvan in the previous century. ${ }^{58}$ The antinomian Kalenders (Ar. Qalandar) were present in medieval Anatolia, but largely absent by the eleventh/seventeenth century. ${ }^{59}$ They were examples of postmedieval concepts of heresy that had become sufficiently established to merit a place in the "library" of theology. At the same time, the heading of "heretical Sufism" provides Şirvānī the space to mention offhand that "in our time, most of the dervishes (ışıllar) by the name of Mevlevis, Gülşenis, or Bektashis are heretics." ${ }^{\prime 0}$ These Sufi orders, which did actively exist in the period, were not placed within Şirvānī's formal list of heresies.

For another example of Şirvānī's approach, we can look at his description of the Bāțtniye, the sect that Kemālpaşazāde regarded as the most dangerous of all. Unlike Kemālpaşazāde, Şirvānī does not consider them particularly vile, but the association of the sect with the Safavids remained strong. Grouping the Băținiye under the general rubric of melāhide (heretics), he says that they "follow no religion (millet) and deny the Creator and the day of Resurrection." ${ }^{61} \mathrm{He}$ then launches into a tale that makes clear his true target - the Safavid dynasty. Şirvānī tells the story of a heretic (zındık) servant named 'Abdullāh el-Meymūn el-Ḳaddāh who sets out on a trip with Muhammad, the grandson of the Shi'i Imam Ja'fār al-Ṣādiq. As the two flee to Egypt, each with their pregnant concubines, Muhammad dies and 'Abdullāh decides to kill Muhammad's concubine in order to declare his own concubine's son as the next Shi'i imam. The charade is believed and the descendants of Persian kings become the false Shi'i imam's staunchest partisans, spreading false belief around the world and becoming quite successful in Iran. The lesson to be taken from Şirvānī's anti-Safavid para-

\footnotetext{
$58 \quad$ Caliphate redefined, 261.

59 Karamustafa, God's unruly friends; De Nicola, The Fusțāṭ al-'adāla.

6o Şirvānī, Risāle 8b-9a; 14b; SK, Ms Darülmesnevi 258, 82a; el-Şirvānī, Tercümânü'l-ümem 326 .

61 El-Şirvānī, Tercümânü'l-ümem 315-316.
} 
ble becomes clear at the end: the heretics drove the Muslim kingdoms into disarray. Most were defeated, even those that attempted in vain to make peace with the heretics. The Muslim world was only purified by the chance arrival of the infidel hordes of Chinggis Khan (d. 624/1227). It is a crude story with a clear message: never make peace with the Safavids.

Şirvānīs main avenue of attacking the Safavids, however, comes through in his description of a seemingly random and spurious sect known as the Benāniye, followers of Benān bin Sem'ān the Jew. ${ }^{62}$ Placing them under the heading of "Extremists" (gulät), whom even the other Shi'ites consider as heretics, ${ }^{63}$ he states that this group believes that God used to inhabit a human form but now only his face remained. In this form

God was incarnated in 'Alī and in the children of 'Alī, just as Gabriel came to the Prophet in the form of Dihye-i Kelbì ... And still today the Reväfiz believe ... that God almighty manifests himself in the form of those heretics, the shahs. For this reason, they prostrate themselves before him as if he were a deity ... and even recognize him as God. There are no heretics worse than this group. They are worse than the Jews and Christians and all the other infidels and it is of utmost importance to eliminate them. No Muslim scholar has any doubts about their heresy. Their harm to the Islamic faith is greater than that of any other infidel. ${ }^{64}$

The choice of the Benāniye as the "sect du jour" differs from that of the other heresiographies, but the main accusation against the Safavids is the same: they consider their kings to be gods. The Ottomans, on the other hand, rely upon the institutions of Islam, rather than on charismatic divine leadership, as Şirvānī suggests when he states that the Benāniye "outright refuse to accede to the sharia courts." 65

Şirvānī might have used the heresiography as a space to make snide attacks against Sufis and the like, but dervishes and Sufis also wrote heresiographies. The other two major heresiographies that emerged during this period were written between 1030-1050/1620-40 and offered a slight alternative to Şirvānī's

62 Benāniye is a corruption of Bayāniyya, which is a sect that appears in some of the medieval heresiographies. Hodgson, Bayān b. Samān al-Tamīmī.

63 On the usage and meaning of gulāt (Ar. ghulāt, from ghuluwww, exaggeration) see Babayan, Mystics, monarchs, and messiahs; Şirvānī, Risāle 8a; el-Şirvānī, Tercümânü'l-ümem 307.

64 Şirvānī, Risāle 8b-9a; el-Şirvānī, Tercümânü'l-ümem 308-309; These claims, too, are borrowed from other treatises, which specifically target the Kızılbaş. Yılmaz, Caliphate redefined, 261.

65 Şirvānī, Risāle 9a; el-Şirvānī, Tercümânü'l-ümem 309. 
screed. A man known only as Derviş Aḥmed, and who was apparently a resident of the Sufi lodge at the Küçük Aya Sofya complex in Istanbul, wrote the The Mirror of belief (Mir'ätül'-'akâa'id). ${ }^{66}$ Before or during his tenure at this Sufi lodge, he was closely attached to the famous shaykh, Mahmūd Hüdāī (d. 1038/1628), who owned and studied one of the few exemplars of the Eastern Hanafi heresiography tradition, al-Firaq al-muftarika, the very same copy that seems to have been the inspiration for Kemālpaşazāde's heresiography in Arabic a century earlier. ${ }^{67}$ This work was apparently also the basis for Derviş Ahmed's translation of the work into Turkish for a wider audience.

Dervīş Ahmed starts his heresiography with the common and compelling point regarding the genre's benefit: the world is full of unbelief and the true Muslim must be prepared to deploy arguments and proof, not just simply recite the basic tenets of belief, if they are to defend the faith, as Tijana Krstić also emphasizes in her essay on contemporary catechisms in this volume. ${ }^{68}$ His work is not radically different from Şirvānīs, but he does retain some of the categories from the older, medieval heresiographical works that Şirvānī had discarded, such as non-Islamic groups. These, though, are primarily schools of ancient philosophy like the Peripatetics, Elementalists (așhāb al-'anāṣir), or Manicheans. Nestled among this group are Jews and Christians, mentioned in passing with no detail. His purpose was not to understand or even refute the theological viewpoints of Muslims or non-Muslims but simply to conjure up a world of unbelief. For this reason, Derviş Aḥmed devotes a very long final chapter to the proper creed and belief of Muslims in the form of questions and answers. ${ }^{69}$

Dervīş Ahmed's heresiography is unique in that it did not have only one intended patron. Instead, the author seems to have tried to dedicate the text to four different government officials: the şeyhü'l-islām Yahyā Efendi (sh.i. 10311032, 1034-1041, 1043-1053/1622-1623, 1625-1632, 1634-1644), two separate grand viziers, Bayram Pasha (g. 1045-1048/1637-8) and Mehmed Pasha (likely Ṭayyār Meḥmed Pasha, g. 1048/1638), and even Sultan Murād IV (r. 1032-1049/ 1623-1640) himself. ${ }^{70}$ The wide variety of government figures here might be

66 On this biographical tidbit, see the colophon of a copy written in 1638 of Dervīş Aḥmed, Mir'ātül'-'akā'id, sK, MS M Arif-M Murad 177, 71.

67 See the statements on the first folios of sk, Ms Süleymaniye 791.

68 Dervīş Aḥmed, Mirāâtül'-akāilid, İstanbul Üniversitesi Nadir Eserler Kütüphanesi, мs T5919, 2 a.

69 Ibid. 23b-25b; İbrahim Hakkı Konyalı Kütüphanesi Ms 594, 59b-64a.

70 See Dervīş Aḥmed, Mir'ātü'l-'aḳāild. Those dedicated to şeyhü'l-islām Yahyā Efendi can be found in SK, MS Özel 276, MS Hacı Mahmud Efendi 1514, MS Serez 3879, Ms Hüdai Efendi 879, MS İzmir 114; Nuruosmaniye Kütüphanesi, MS 2144; İbrahim Hakki Konyalı 
interpreted as a sign that Derviş Ahmed had some difficulty in finding a sponsor interested in his work, but it also shows how many high-level officials an enterprising author could appeal to for sponsorship of such material in the 1630 s. This interest would continue as one copyist noted that he copied the treatise in the presence of Sultan Mehmed IV (r. 1058-1099/1648-1687) and the chancellor Nişāncı Mehmed Pasha. ${ }^{71}$ The interest in these works by the highest state officials makes sense given that the Ottomans had reignited their war with the Safavids once again, and many of these officials were directly involved in the reconquest of Baghdad from the Safavids in 1048/1638. Although Şirvānī was the only writer who directly censured the Safavids, the heresiographies coincide neatly with the timeline of the Ottoman-Safavid wars.

Derviss Ahmed's work might have enjoyed the direct support of the highest echelons of the Ottoman state, but it was Nūḥ b. Mușțafâ’s (d. 1070/166o) book that became the authoritative, if lightly read, heresiography in the empire. Nūḥ b. Mușțafā was a prolific Rumi scholar and preacher who lived primarily in Cairo after serving briefly as mufti of Konya. ${ }^{72}$ A certain Yūsuf Efendi in Cairo pushed him, sometime in the 1040s/1630s, to translate the aforementioned sixth/twelfth-century heresiography of Shahrastānī into Turkish. ${ }^{73}$ As mentioned earlier, Shahrastānī had written one of the most canonical versions of the genre, imbuing it with a certain latitudinarian approach, and Nūh b. Mușțafä deeply edited it in his Translation of religions and sects (Tercüme-imilel ünihal).

In many ways, Nūh b. Muștafâ’s work returns to the genre's scholarly roots while continuing to dismantle the irenic air found in Shahrastānìs original. Despite its excision of key parts of Shahrastānīs text, it was the longest of the Ottoman heresiographies due to its inclusion of elaborate descriptions and refutations of the medieval theological heresies. In comparison, Dervisş

Kütüphanesi, MS 594; İstanbul Üniversitesi Nadir Eserler Kütüphanesi, Ms T40oo. To Sultan Murād IV: SK, Ms Reşid Efendi 984, Ms Yazma Bağışlar 74. To Bayram Pasha: SK, MS Şehid Ali Paşa 1723, MS Asır Efendi 183, İstanbul Üniversitesi Nadir Eserler Kütüphanesi, MS T5919, MS T5923. To Meḥmed Pasha: SK, Ms Şehid Ali Paşa 1723. With no dedication: SK, MS M Arif-M Murad 177.

71 SK, Ms M Arif-M Murad 177, f. 71.

72 Little research has been done on Nūḥ b. Muștafāa, a fascinating figure and major author of the eleventh/seventeenth century. For basic biographic information, see Yaşaroğlu, Nûh b. Mustafa xxxiii, 230-231.

7314 Şa'bān 1049/10 December 1639 is the earliest copy date of a collated copy of Nūh b. Mușțafā's work written by Ebu Bekr b. Halīl al-Diyārbakrī al-Ḥanafì for Muștafā Kethüdā and copied from the author's copy. SK, MS Fatih 2913, 118b-119a. 
Aḥmed, Şirvānī, or Kemālpaşazāde, who based their works on the Eastern Hanafi model, were satisfied with a cursory description of each sect and its respective heresy, paying little attention to historical accuracy. Nūḥ b. Muștafā, on the other hand, provides details. For example, his translation of Shahrastānī's Religions and sects adds small bits to the original, such as longer discussions about some of the newer philosophical and theological points that the Mu'tazilites had originally raised, but he also inserts refutations of most of the sect's core ideas. ${ }^{74}$ At the same time, he excises nearly all mention of the Iranian and Indian religions and the segments on Jews, Christians, and philosophers are heavily reduced. ${ }^{75}$ In its place is a large section outlining the proper belief of the elect sect, fırka-yı nāciye (i.e., Sunnism). Nūḥ b. Mușțafā rewrites Shahrastānì's opus for a new era by focusing more on Muslim heresy and proper Sunnism than on the diversity of humanity's beliefs. At the same time, behind the radical edits, there remained a modicum of analytical distance in Nūh b. Muștafâ's approach in comparison to that of his contemporaries. For example, his entry on the Benāniye has none of Şirvānī's animus, and he takes out Shahrastānìs separate section on extremist Shi'is (gulät) and merges it into the last chapter of the Shi'ites on the Ismã ilize. Here he mentions the Bäțtniye, the sect that Kemālpaşazāde so despised, yet his tone is measured. He includes some harsh words only in the last sentence, in which he castigates them for letting their esotericism lead them to reject the sharia and the other sciences due to their fear of reading. ${ }^{76}$

\section{$5 \quad$ Reading Heresy into the Ottoman World}

The eleventh/seventeenth century saw the expansion of heresiographies as a wider group of authors began writing for a reading public that was now actively interested in the notion of heresy. But did these authors' crude insinuations against the Safavids, Kızılbaş, and other religious deviants hit their marks? What meanings might Ottoman readers have drawn from these texts on timeless heresies? This is a question that cannot be easily answered by only scrutinizing the ideas and intentions of the authors, and instead we have to turn to the reception of these texts through an analysis of the manuscript

74 Nūḥ b. Mușțafā, Tercümetü'l-milel ve'n-nihal 15-36.

75 For a general overview of the content of the text, see Özkılıç, Sunnitization through translation 61-85.

76 Nūḥ b. Mușțafā, Tercümetül-milel ve'n-nihal 43-47. He also has an interesting section on how the Isma'ilis convert others to their cause. 
record. A brute count of remaining manuscripts provides us some hints as to their reception, but this can often be misleading, as discussed previously with Shahrastānìs text. Another problem is that readers rarely ever left personal comments or thoughts on their manuscripts, the kind that might help us associate a historical sect with a segment of Ottoman society. ${ }^{77}$ In its place, we have to analyze scripts, collation marks, colophons, or the absence thereof for clues as to the texts' receptions among different groups in Ottoman society. Most importantly, we can read patterns of associations that copyists, binders, and readers made when they decided to group one heresiography with another text in miscellanies (mecmü $a$ s) from the tenth/sixteenth to twelfth/eighteenth centuries. This method allows us to discover texts that might otherwise be overlooked — as was the case in my discovery of Dervīş Aḥmed's heresiography - and to take into consideration instances when heresiographies were not read as full and coherent texts, but as partial pieces such as introductions or rubrics.

This method demonstrates that the heresiographies came to be used as much, if not more so, to identify heresy within Ottoman society itself during the eleventh/seventeenth and twelfth/eighteenth centuries as they were to paint the foreign Safavid enemies as heretics. Well after the Ottoman wars against the Safavids came to a formal end in 1049/1639, the conception of heresy that the heresiographies fomented continued to spread. As mentioned in the introduction of this essay, the historiography on the confessionalization of the Ottoman Empire has tended to emphasize either the external threat of the Safavids or the internal motor of Sunnitization, but an analysis of the reception of these texts in the eleventh/seventeenth century allows us to understand where and how these two contexts intersected. In addition, this form of analysis shows us how Ottoman readers applied heresiographies to their daily lives and used them as a means of categorizing the world.

An analysis of reception is possible because the works were simply much more widely read and copied in the eleventh/seventeenth and twelfth/eighteenth centuries compared to the tenth/sixteenth. In fact, the tenth/sixteenthcentury heresiographies appear to be even more marginal because they are never referenced, read, or grouped together with the much more popular heresiographies of the following century. Lüții Pasha's tenth/sixteenth-century treatise only exists in one or possibly two copies from the late eleventh/seventeenth

77 The one exception I found is a very condensed Arabic version of Shahrastānīs text in a late twelfth/eighteenth-century (1194/1780) notebook in which the reader notes on the side of one of the heresies that "this is the state of our scholars today." SK, MS Reşid Efendi 985, 93-108. 
and twelfth/eighteenth centuries. As for Kemālpaşazāde's treatise, a respectable eight copies remain of it, but they are all in large anthologies devoted to his work, often owned by muftis and judges, many of which were created in 967-988/156o-1580. ${ }^{78}$ The readership of the heresiographies matches Kemālpaşazāde's intended audience of muftis and judges who, as his heresiography notes, might rule on validity of jizya payments and adjudicate disputes in the provinces. In dangerous lands full of errant beliefs, these men would cart along the compiled treatises of the master jurist as a reference work. In contrast, in Istanbul alone there are about 30 copies of Nūh b. Muștafâ’s translation and 20 copies each of Şirvānī's and Dervīş Aḥmed's work, with more found in libraries across the world. But crude metrics reveal only part of the picture.

When we look at the manuscript miscellanies containing eleventh/seventeenth-century heresiographies, we notice first of all that the texts of Şirvānī, Dervīş Aḥmed, and Nūḥ b. Mușțafā were often copied and bound together, demonstrating an organic connection that Ottoman subjects forged between the texts. ${ }^{79}$ More often, they were grouped with other treatises on relevant topics as will be discussed below. While this might be a matter of convenience or coincidence, we can read purpose into these choices by analyzing those miscellanies that were made by the same copyist or bound together topically. Not surprisingly, we find the heresiographical texts placed alongside refutations of Safavids and the Kızlbaş in the miscellanies. ${ }^{80}$ The reciprocal connection between the Ottoman-Safavid wars and the heresiographies is seen most clearly in one copy of Şirvānīs heresiography copied in Baghdad in the year 1035/1626, during the time of governor Hiâfiż Aḥmed Pasha. The timing and location are significant: the Ottomans had just reconquered

78 See, for example, SK, Ms Hamidiye 186, 147-148 copied around Safar 989/March 1581; MS Kılıç Ali Paşa 1028, 296-297 written between 985-986/1577-1578 written for a Molla Ahmed b. Süleymān, owned by the mufti of Kayseri. Ms Pertev Paşa 653, 161a-163b has no copy date but seems to be done by the same scribe as the previous two copies; MS Reisülküttab 1196, 37b-38b is in a mecmū'a copied around late 996/1587. Ms Nuruosmaniye 4972, 104-106 was copied around 977/1570. I was not able to inspect the copies at Beyazit Devlet Kütüphanesi, Ms Beyazit 5999, 131a-133a and 8046, 101a-103a but both are in large meсmū'as devoted to Kemālpaşazāde.

79 E.g., SK, MS Ozel 276, Ms Hüdai Efendi 879, MS Izmir 114; Nuruosmaniye Library MS 2144.

8o Anonymous, Risāle fì hurūc-i Şāh İsmāîl ve țăîfe-i Kııılbaş, Nuruosmaniye Kütüphanesi MS 4976, 124-125 alongside Şirvānī, Risāle, MS 4976, 12-19, although separated in space, the two treatises were written by the same scribe. Miscellany containing Şirvānī's Risāle with comments on the Kızılbaş, SK, Ms Tercüman 262. See Nūḥ b. Mușțafā, Tercüme-imilel ü nihal, sK, Ms Ayasofya 2197, 1-153 grouped alongside Kạḍīzāde đílmī Meḥmed b. Mușṭafā,

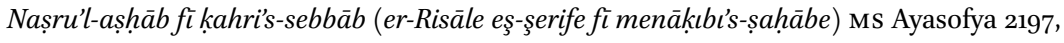
154a-181a, which is a treatise about defining religious deviations (bid'at). 
Baghdad from the Safavids as part of the third Ottoman-Safavid war (10321049/1623-39). Şirvānīs heresiography now provided a template for judging the fidelity of their newly reconquered subjects. ${ }^{81}$ Read and copied throughout the eleventh/seventeenth and twelfth/eighteenth centuries, the heresiography tradition would revive whenever this particular fight reignited, such as the fourth Ottoman-Safavid war (1142-1148/1730-5). ${ }^{82}$ In fact, the continuing influence of the heresiographies might have undermined the efforts of government-affiliated Ottoman jurists to rehabilitate the Safavids as Muslims during peace time, as discussed by Selim Güngörürler in his contribution to this volume.

Yet, the miscellanies reveal not only that heresiographies were read in the context of foreign wars with the Kizllbaş and the Safavids but also alongside polemical treatises on the burning questions of the period. One miscellany from 1093/1682 containing Şirvānīs heresiography was written by a certain Muhammed b. Hasan b. Süleymān, who copied in the same volume and within the same month treatises by the firebrand Rūmī Aḥmed Aḳhișāin on the abominable practice of performing $\underline{z} i k r$ and smoking tobacco. ${ }^{83} \mathrm{~A}$ heresiography from 1068/1658, most likely copied in Egypt, was read alongside treatises on the legality of coffee. ${ }^{84}$ Other groupings point to similar reading patterns: the heresiographies are found alongside works by the late tenth/sixteenth-century scholar Birgivī, more works on twirling during Sufi worship sessions (deverān), the tract of the aforementioned Rūmì Aḥmed, şeyhü'l-islām Minḳārīzāde's treatise on whether or not Muslims may call themselves part of "the religion of Abraham" (millet-i İbrähìm), and more. ${ }^{85}$ Heresy now lurked behind every sip of coffee or innocuous statement.

81 See the colophon of miscellany containing Şirvānī's treatise along with Sivāsìs Dürerül'akāid, sk, Ms Çelebi Abdullah 195 .

82 See a new heresiography text, which is modeled from the discussions of Taftāzānīs Sharh al-maqāsid: Mușțafā al-Islāmbūlī, Risāla fí-l-farq al-Islāmiyya, Egyptian National Library and Archives, MS Majāmī` Tīmūr 345, 116-162.

83 Miscellany containing Şirvānī’s Risāle and Rūmī Aḥmed Aḳhiṣārì’s treatises on tobacco and $z i k r$, sk, Ms Darülmesnevi 258, 7ob-109b.

84 Khalīl b. Yūsuf al-Zubayrī al-Budhuwānī, al-Risāla al-saniyya li-márifat al-madhhab alsawiyya, National Library of Israel, MS AP Ar. 499, 13a (unfortunately the rest of the treatise is cut off).

85 Miscellany containing Dervīş Aḥmed's work with Kitāb-i Rūmı̄ Aḥmed Efendi, Birgivī's Terceme-i inkāazült-hālikin, and a commentary on Fiqh akbar, sk, MS Yazma Bağışlar 3842; miscellany containing Şirvānì's Risāle, Birgivī's Terceme-i inḳäzü̈l-hālikin and Millet-i İ̉rāahìm treatises, MS Mihrişah Sultan 440; miscellany containing Şirvānīs Risāle, Birgivī's various works, and deverān treatises, Ms Harput 11. 
One of the eleventh/seventeenth-century heresiographies, that of Nüh b. Mușțafā, however, had a very different material life and readership than its contemporaries. His translation of Shahrastānī's Religions and sects was copied (and eventually printed) more than any other heresiography of the period. Its success might even have revived interest in the original Arabic text of Shahrastānī, with numerous twelfth/eighteenth-century libraries in Istanbul collecting reliable medieval copies of the text, which were then used to make new copies of the Arabic version. ${ }^{86}$ Yet, the numerical popularity of Nūh b. Muștafā's translation is belied by the rather meager engagement of readers. It was a similar scenario with his other major work, a tertiary commentary of al-Durar, which elicited complaints from colleagues that it was far too long and too selfreferential. ${ }^{87}$ Whereas Şirvānī's and Dervīş Aḥmed's texts were often grouped with a variety of other short, polemical treatises, copied in simple but legible hands in a relatively cheap manner by scholars who wished to read them, Nūḥ b. Mușțafā's work tended to be placed in nicely produced and calligraphic, but starkly empty, manuscript editions. Marginalia on these works is largely nonexistent, nor are there many collation and correction marks-a sign that readers are actually interested in reading the content of a long work-or even the signatures of the copyists, which suggests it was copied by professional scribes creating display copies and sold by booksellers. ${ }^{88}$ Unlike the copies of

86 An excellent example of the later collection of medieval heresiographies is a mecmūa created in 1160/1747, which contains verified and collated copies of Shahrastānī and Ibn Hazm's heresiographies from $722 / 1322$, with a small introduction to the genre's main medieval representatives from Ḥājji Khalīfa (Kātib Çelebi), Kashf al-zunūn. sk, Ms Reisülküttab 555. Twelfth/eighteenth-century libraries often functioned as scriptoria, collecting reliable copies of old texts that would serve as the basis of new copies. For a list of medieval copies collected by these libraries, see footnote 22 above. Sezer, Architecture of bibliophilia. Examples of late eleventh/seventeenth and twelfth/eighteenth-century copies include sK, MS Mahmud Paşa 302 (copied in 1086/1675-1676, see notice on the first folio); Ms Laleli 2445 (copied in 1099/1687-1688); MS Reisülküttab 157 (copied in 1135/1722-1723); Ms Laleli 2165 (copied in 116o/1747). There are also summary versions of Shahrastānīs Arabic piece from the eighteenth century, like Ms Reşid Efendi 985, 93-108 (from 1194/1780) and Ms Düğümlu Baba 449, 166-173 (written in 1157/1745-1746).

87 The work is Natāïj al-nażar fi hạshiyyat al-Durar, which exists in ten or so copies in Istanbul. See Anonymous biography of Nüḥ b. Muștafā, sk, Ms Halet Efendi Ek 70, 107a. Interestingly, the biography does not mention his heresiography as a particularly important work of his.

88 For nice display copies, see sk, Ms Hacı Mahmud Efendi 1289, Ms Hacı Mahmud Efendi 129o; MS Halet Efendi 417, Ms Hamdiye 720, Ms Hekimoğlu 823 (this one was meant to have illumination, but it was never completed), Ms Lala Ismail 257, Ms Nuruosmaniye 2100, Ms Laleli 2164; Istanbul Üniversitesi Nadir Eserler Kütüphanesi, Mss T2286, T2272, T2098. There are obviously exceptions to this, such as the two copies with collation marks 
Kemālpaşazāde's text, carried into the field by judges in large compendia, or Şirvānī's, which was read by pamphleteering polemicists, Nūḥ b. Mușțafā's text was a reference work meant to be positioned ostentatiously on the shelf of an administrator or used as an academic reference work. Not surprisingly then, the owners and patrons that commissioned these copies tended to be pashas, fortress commanders, and janissary chiefs. ${ }^{89}$

The connection between the heresiographies and these debates on Muslim piety was so close that there emerged in the mid- to late eleventh/seventeenth century a pseudoepigraphical heresiography attributed to the tenth/sixteenthcentury pietist Birgivī Mehmed. ${ }^{90}$ Much like the other heresiographies, it contained a declaration of Sunni beliefs, and, in the miscellanies that it contains, are grouped other works that address basic Muslim legal obligations, like prayer, and other creeds. ${ }^{91}$ Pairing a heresiography with a creed outlining

in SK, MS Fatih 2913 and MS Esad Efendi 1149. For copies acquired by booksellers, see sK, MS Hacı Mahmud Efendı 1516 and Ms İbrahim Efendı 503.

89 See SK, MS Fatih 2913 commissioned by a Mușțafā Kethüdā in 14 Şaban 1049/1o Dec 1639; MS Fatih 2912 copied by Meḥmed b. Mușțafā, the scribe of Zāl Maḥmūd Pasha in 15 Şaban 1134/31 May 1722; MS Hekimoğlu 823 owned by Ḥekīmoğlu 'Alī Pasha b. Nūḥ in 1147/17341735; Ms İbrahim Efendi 503, copied by Mehmed b. Velī, the Janissary scribe in the fortress of Vidin in 17 Rabia I 1158/19 April 1745, who also seems to have copied the manuscript at MS Laleli 2165 in 116o/1747; MS Sütlüce Dergahi 65, which was copied from the copy of Seyyid Meḥmed Çorbacı, müstahfızān of Cairo; Istanbul Üniversitesi Nadir Eserler Kütüphanesi MS T2286, 138b-140a, in which the scribe Ismāîl writes a kasīde upon finishing his copy in 1062/1651-1652 in praise of the patron Emīr Halīl, a mìr-livā. Sadberk Hanım Müzesi, MS 8o, copied by Ibrāhīm for Aḥmed, kethüdā-imüstahfizānn of Cairo in ${ }_{27}$ Rabia II 1140/12 December 1727 and later owned by Hāşim Kethüdā b. el-Ḥāc Ebūbekir Pasha.

$90 \quad$ Pseudo-Birgivī, Tuhfat al-mustarshidīn fì bayān firaq al-Muslimīn. SK, MS Fatih 5344 (copied in 1188/1774-1775); Ms Damad İbrahim 297, 377-384 (copied in Receb 1101/AprilMay 169o); Ms Yazma Bağışlar 5778, 19-38 (not dated but most likely twelfth/eighteenth century); MS A. Tekelioglu 824ff. 93a-99 (copied in 29 Safer 1263/16 February 1847); Beyazit Kütüphanesi, MS 1463, 81a-9oa (n.d.); Atıf Efendi Library Ms Ek 1500, 149b-157a (copied 30 Muharrem 1199/13 December 1784); Tokyo University Daiber Collection, Ms 32, 30a-35b (copied in 126o/1844-1845). As noted with the dates of these works, I agree with Ahmet Kayli, who argues that this work is one of the many pieces falsely attributed to Birgivī in the eleventh/seventeenth century, given the dates of extant manuscripts; A critical study of Birgivi Mehmed Efendi's works 134-135; van Ess claims that this heresiography was dedicated by Birgivī to (Kara) Ahmed Pasha, who lead a campaign against Shah Tahmāsp in the mid-tenth/sixteenth century. Van Ess's proof, though, is a reference in Brockelmann's GAL (Berlin 2133/4) that he seems to have misread. It is actually the previous treatise mentioned by Brockelmann (Berlin 2132) that is a refutation of the Shi'ites and is dedicated by Birgivī to a certain Ahmed Pasha. Van Ess, Der Eine ii, 1178-1179; Brockelmann, History of the Arabic written tradition ii, 518 .

91 SK, Ms Yazma Bağışlar 5778, which has the Fiqh akbar, a list of sins by Turkistānī 'Alaeddīn, and variety of others. See also Beyazıt Devlet Kütüphanesi, MS 1463 and Atıf Efendi Kütüphanesi MS Ek 1500. 
basic beliefs of faith was a quite common practice, and we find heresiographies grouped alongside the famous creed of Nasafi or the new ones of shaykhs like 'Abdü'l-mecīd Sivāsī (d. 1049/1639). ${ }^{92}$ Sometimes just the segment on the "elect sect" of Sunnism was copied out to function as a creed ('akäid). ${ }^{93}$ The reason for these associations is simple. As the author of one anonymous heresiography (which was copied alongside a commentary on the Figh akbar in the late eleventh/seventeenth century) stated, it was a way of ferreting out "hypocrites, those who outwardly display Islam but conceal their heresy and infidelity deep within."94 Together these associations demonstrate not only how the heresiographies were used to frame fights over Muslim practice in the eleventh/seventeenth century but also how closely tied they were to the confessionalization of the empire.

Readers of heresiographies in these varied contexts might have been less interested in the details of the sects themselves than the image these texts conjured of an Islamic world besieged from within and without by heretics. This motivation helps explain those instances when a reader would copy only the introduction of one of the heresiographies, which repeated the famous hadith that Muslims were bound to divide into 72 wayward sects and reiterated the need to ferret out the hypocrites and dissimulators. ${ }^{95}$ An equally common phenomenon was to reduce the heresiography to its base schema, a one-folio table of the 72 wayward sects that simply listed their names and two or three words of description. ${ }^{96}$ Heresiographical "modules" were likewise incorporated in longer texts for similar purposes. ${ }^{97}$ Take, for example, a long, anonymous text written during the time of Murād IV, and which was floridly dedicated to his grand vizier, Mehmed, who had established the madrasa at which the author taught. The manuscript is currently missing its first few pages, which makes the author and title difficult to decipher, but it is essentially a large work in

92 For Nasafī, Aqā̉id, see sk, Ms Hacı Mahmud Efendi 1413, and for 'Abdü'l-mecīd b. Muharrem el-Sivāsī, see Dürerü'l-'aḳā'id, sk, Ms Çelebi Abdullah 195, 3ob-1ogb.

93 Al-Şirvānī, Risāle fi Beyān mezzāhib muhtelife, sK, MS Mihrişah Sultan 440, 27a-28b.

94 Anonymous, Untitled heresiography, sk, Ms Hacı Ahmed Pasa 156, $193 \mathrm{~b}$.

95 Derviss Aḥmed, Mir'ātü'l-'akā'id, sk, ms Yazma Bağışlar 3842, 57b-59b; National Library of Israel, Ms Yah. Ar. 311, 6oa.

96 See, for example, the late seventeenth-century mecmū'a of Mușțaā b. 'Abdü'l-ḥalìm from Antep, National Library of Israel, MS AP Ar. 482, 170a-171a; Atıf Efendi Kütüphanesi, MS 2817, 67b-68a, copied in 1102/1691 from the text of a certain shaykh Ekmele'd-dīn. The copyist, Ahmed Ismācil of the Haseki neighborhood of Istanbul, made the mecmū'a over the last decade of the seventeenth century (from 1103-1104/1691-3).

97 See, for example, the giant work of Najm al-Dīn al-Ghazzī from the early eleventh/seventeenth-century Damascus. al-Ghazzī, Husn al-tanabbuh ix, 347-465. This is the rare case of finding a heresiography in Arabic sources from the period. 
quite simple Turkish explaining the perfection of the Quran, the various types of unbelief (kufr), and general problems in dogma among the population. The first chapter, though, is a heresiography, and introduces the core question framing the book: "what is the reason for the divisions in Islam?"98

This reading of the heresiographies as a means of imagining or organizing the world can help us understand the curious comments on the heresiography genre made by the eleventh/seventeenth-century bibliophile Kătib Çelebi (d. 1067/1657). In his massive bibliography Kashf al-zunūn, he states that while the genre of milal wa-l-nihal is comprised of the medieval heresiographies of people such as Ibn Hazm and Shahrastānī, and translated lately by Nūh b. Mușțafā, there exists a popular understanding of the genre as a means of dividing the world and categorizing human difference. Copying from the introduction (without attribution) of the aforementioned anonymous heresiography dedicated to Murād IV, he states that some classify humans according to their environment, with each of the seven climes imparting onto people different tongues and colors. Others divided the world according to the cardinal directions, or by the major civilizational groups (umam) —Arabs, Persians, Turks $(R \bar{u} m)$, and Indians. Finally, some people, such as our heresiographers, split the world according to beliefs and sects (al-ärā'wa-l-madhähib). ${ }^{99}$

This broader notion of heresiography as a classificatory schema for human civilization had always been present. The medieval poet Yūnus Emre frequently interchanged the phrase " 72 sects (millet)" with " 72 tongues (dil)," in which the heretical Other became synonymous with the diversity of peoples in the world: "He created seventy-two types of tongues / And placed the Muslim above them all."100 Shahrastānī's Religions and sects likewise continued to be used to understand the non-Muslim world. When the traveler Ibn Ma'șūm (d. 1120/1708) departed as a boy from Mecca to Hyderabad in 1066/1655-1656 to join his father, he used the relevant sections on animists and water-worshippers to briefly describe and contextualize the Hindu practices he encountered. ${ }^{101}$ This fits with the traditional role of heresiographies as a means of describing the world at large, just as we saw with the classification of Shahrastānì's travelogues in the imperial library of Bāyezīd II. Thus, it is not surprising to find Ottoman scholars like Kemālpaşazāde and Şirvānī mention on occasion that a

\footnotetext{
98 Egyptian National Library, Ms Tawhid Turki 48, 2a. The cataloger lists the author as Yackūb b. 'Abdü'l-lațîf, but it is unclear how s/he concluded this.

99 The original heresiography can be found in the Egyptian National Library, Ms Tawhid Turki 48, 3b. Ḥājji Khalīfa (Kātib Çelebi), Kashf al-zunūn ii, 1821.

100 "Yaratdıyitmiş iki dürlü dili| arada üstün kodımüsülmânı."Yunus Emre, Yûnus Emre Dî̀ânı: tenkitli metin ii, 401. See also 197, 218, 405.

Ibn Ma'ṣūm, Rihlat Ibn Mașūm 162.
} 
certain medieval sect had followers in Georgia, Persia, Azerbaijan, or Egypt. ${ }^{102}$ Heresiographies written during the Ottoman period continued this tradition. Not only did they cast the world as an island of proper Sunnism surrounded by an ocean of heresy, but they also defined the world as divided first and foremost by confessional differences.

A sectarian worldview was not a foregone conclusion, however, but a phenomenon that emerged out of the particular dynamics of the Turkish-speaking parts of the Ottoman Empire. Something about these heresiographies simply did not move into Arabic. While Arabic readers could, of course, refer back to the medieval originals, there is a noticeable lack of adaptations and epitomes of heresiographies in Arabic. ${ }^{103}$ And although Nūḥ b. Mușțafā wrote his translation in Cairo, it was for a Turkish-speaking Rumi audience and it seemed to make few inroads with the local Arabic-speaking scholars. In fact, these texts seem to be much rarer outside of the core Turkish-speaking areas of the empire. When an Egyptian copyist in 1068/1658 needed to access a shortened and more modern version of the heresiographies, he had to avail himself of a version that was produced in the Gujarati Sultanate in the ninth/fifteenth century, rather than a locally available copy. ${ }^{104}$ It is important to keep this in mind because the strongest resistance to the insistent drive to anathematize Muslims came from the scholars of the Arab cities. ${ }^{105}$ While the imperial center continued to try to divide the world into heretics and believers, this was not a universally accepted aspiration for all Muslims in the empire.

102 For example, the Karrāmiye is found in Gürcistān (Georgia), Şirvānī, Risāle, sk, Ms Darülmesnevi 258, 81a; Kemālpaşazāde, Risāla, Ms Reşid Efendi 1031, 281a.

103 Van Ess, Der Eine ii, 1175-1182. Relying on Brockelmann, van Ess lists a number of heresiographies that were written in the Arab lands during the early modern period. It should be pointed out, however, that these seem to be nonexistent in the Turkish-speaking parts of the empire, never copied or read with the main current of heresiographies. This point reinforces the necessity of examining the manuscript copies themselves.

104 Khalī b. Yūsuf al-Zubayrī al-Budhawānī, al-Risāla al-saniyya li-márifat al-madhhab alsawiyya, National Library of Israel, MS AP Ar. 499, 12a. Although the copyist does not identify his location, you can tell it is Cairene by the Arab naskh script it employs and the fact that it is dedicated to the Bakrī Sayyids, a powerful Sufi ruling family in eleventh/seventeenth-century Cairo. As mentioned earlier, the early eleventh/seventeenth-century Damascene scholar, Najm al-Dīn al-Ghazzī, included one in his encyclopedic work, but more as an act of comprehensiveness than a central and updated part of the text, I believe. AlGhazzī, Husn al-tanabbuh.

105 See, for example, the work of Qāsim al-Khānī, the late eleventh/seventeenth-century Aleppan scholar who wrote a few treatises critiquing Şirvānī's eagerness to declare all Muslims heretics. Egyptian National Library and Archives, Ms Majāmī' Ṭa lat 335, 1-21. It seems that Khānī is not responding to the heresiography but to another text of Şirvānī or possibly his grandson, the şeyhü'l-islām, Meḥmed Șādık Șadre'd-dīnzāde. 
While Arab scholars were perhaps less receptive to Ottoman-style heresiographies, the texts, and a larger conception of a world divided into heresy and belief, found an audience beyond the borders of the empire. The most fascinating rendition of the Ottoman heresiographies comes from an unlikely source. They are two copies-one in Judeo-Turkish and the other in rough Italian - of Şirvānìs heresiography from the first decades of the eleventh/seventeenth century. A Judeo-Turkish copy of Şirvānīs heresiography, apparently the earliest copy extant, was copied, shortly after Şirvānī wrote his treatise, on a scribe's defter-formatted pages. ${ }^{106}$ Although the Hebrew script used is quite difficult to read today, it seems to be relatively faithful to the text. It was eventually acquired by Levinus Warner (d. 1665), the Dutch consul resident in Istanbul, and made its way to Holland. Warner resided in Istanbul from $1055^{-1075 / 1645^{-6}}$, so the text was not originally intended for his consumption. Before it reached Warner's hands, though, it likely found its way into the possession of Yahacob (Ya'acov/Jacob) Romano. On 10 July 1632, Romano presented his translation of Şirvānī's heresiography in a very rough and "vulgar Italian" to the king of France and his ambassador in Constantinople where it eventually made its way into the French royal library, copied into a book of reports. ${ }^{107}$ The translation was actually one of three books he left for the French delegation upon leaving Istanbul for Jerusalem. ${ }^{108}$ This sort of work was common for Romano, who, besides attempting to establish a trilingual press (Hebrew-LatinArabic) in Istanbul, was a frequent book supplier and correspondent with the elder and younger Johannes Buxtorf, the famous Swiss Hebraicists. ${ }^{109}$

For the most part, Romano is faithful to Şirvānīs Turkish text, displaying only a few mistakes in his grasp of the original text while doing his best to render

106 The manuscript has some clear but oddly written Arabic (in Arabic script) on the back thanking God for placing them in the elect sect (al-firqa al-nājiya). Şirvānī, Risāle fi Beyān mezzāhib muhtelife (Judeo-Turkish version), Leiden University Library, MS Or $1129(\mathrm{~g})$.

107 Bibliotheque Nationale de France, Manuscrits occidentaux, Francais 16141, 348-388, especially 348 . My sincere thanks to Tijana Krstić for bringing this translation to my attention. Şirvānī, Risāle, MS Francais 16141, 348.

108 Those three books are "al-Tarjaman," which was an Arabic-Persian-Turkish lexicon written in 1629; Şirvānī's "compendium of various sects which are found among the Muslims (turchi)"; and, finally, its translation from Turkish into a crude Italian. It is suspected that the Judeo-Turkish text found in Leiden was the piece that Jacob Romano used for the translation. Steinschneider, Zur arabischen Literatur 841.

109 Van Ess mistakenly states that Romano was trying to print Şirvānī's heresiography. Van Ess, Der Eine ii, 118 o. It is clear from the Hebrew, though, that Romano actually wanted to publish a trilingual edition of Maimonides Guide to the perplexed. For a list of books provided by Romano, see Kayserling, Richelieu, Buxtorf père et fils, Jacob Roman 93. 
the Turkish into a crude Italian. ${ }^{110}$ For example, keläm, that is, theology, is rendered as "Philosophia" and 'ulemä become "vicari." Yet hidden within Romano's translation is a more surprising intervention. Toward the conclusion, the word "Catholics" starts to appear throughout the text. Romano has not changed the substance of the text though. Instead, he has gone through and substituted "Catholici" whenever the original work mentions (Sunni) Islam or Muslims. He provides no explanation for this, but he begins this substitution at the end of the treatise, that is, in the section where Şirvānī starts to describe the "elect sect" of the "Ehlisunnet et Giemahet," (i.e., the Sunnis). After listing Şirvānī's six "sects" or legal schools of Sunnism ("hanifia, Maliquia, Xafihia, hanbalia, sofinia [sufyaniyye], sevria"), Romano states that their beliefs are far from heresy and "the sum of these opinions of the Catholics is this," whereupon he moves on to the description of the basic tenets of Sunni theology and continues to use the word Catholics to refer to Muslims. ${ }^{111}$ Romano translates Sunnism into Catholicism lest his European readers believe that the "ehlisunnet et giemahet" were just one more group of wayward heretics. Every Ottoman heresiographer had to use his authorial prerogative to translate the past into terms comprehensible to the reader of his day, and Romano is no different.

By making this remarkable association, our Jewish author is proposing a new, confessionalized vision of the world. Yet, Romano's heresiography was not just another sectarian text decrying Islam's heresies to a Christian audience. Nor is he describing a world in which Islam and Christianity were battling one another for supremacy of the Mediterranean and the world. Instead, he is suggesting that the Sunni Ottoman Empire and the Counter-Reformation Catholic kingdoms were actually united in their parallel struggles against heretics, whether that of the Shi'ites, Protestants, or others. It is an intriguing vision of a world united by confessionalization rather than divided by sectarianism.

Of course, a view of the world as divided according to confessions was just one possibility among many, but it found a ready currency among many in the Ottoman Empire. As I have traced out in this paper, the dynasty's relative indifference to matters of confessional fidelity in the ninth/fifteenth

110 One place where Romano mistranslates the text is the section on the Benanniye, a sect, mentioned above, that believes that God is incarnate in the children of 'Alī, just as the angel Gabriel had incarnated in Dihye-i Kelbī. Romano, unfamiliar with this companion, interprets kalb literally, stating that the angel Gabriel appeared in the form of a dog (cane). BNF MS Francais 16141, 366v. The French copyist was also careful to fix copyist mistakes and note where Romano had accidently repeated himself (e.g. 375v, 38or).

111 "l'opinioni di questi sonno lontane dalle Inventioni et opinioni delli Infideli et la somma di queste opinione de i Catholici e questa," BNF MS Francais 16141, $384 \mathrm{v}$. 
century was shattered by the threat of the Kuzılbaş and the Safavids in the early tenth/sixteenth century. In reaction, government-affiliated scholars set out to (re)define heresy, and the medieval genre of the heresiography was dusted off and retrofitted for a new era of theological rivalry, no longer a guide to the bizarre beliefs of distant peoples but a means of anathematizing tangible enemies. However, they never added, or even mentioned, new heretical sects to the ancient lists. Instead, they subtly and crudely alluded to parallels between medieval groups and current opponents. These limited writings in the tenth/sixteenth century found renewed popularity among a wide range of authors and readers in the eleventh/seventeenth century following the second and third Ottoman-Safavid wars. Even after hostilities had ceased, there remained a widespread desire to identify and root out heresy within Ottoman society itself as readers began to read the heresiographies alongside tracts against smoking tobacco and other controversies. In this way, Ottoman subjects learned to read heresy both in the beliefs of the empire's enemies abroad but also at home, among their coreligionists in the same city and town. We can only see the historicity of this genre, however, if we learn to read the varied traces of evidence left behind on the material manuscripts themselves.

\section{Acknowledgments}

I would like to thank the editors of this volume, Tijana Krstić and Derin Terzioğlu, as well as the anonymous reviewers for their very insightful comments on earlier drafts. Research for this essay was supported by the European Research Council (E RC) Consolidator Grant under the European Union's Horizon 2020 research and innovation program (grant agreement No 648498).

\section{Bibliography ${ }^{112}$}

Allouche, A., The origins and development of the Ottoman-Safavid conflict (906-962) 1500-1555), Berlin 1983.

Altıntaş, R., Şirvânî, Sadreddinzâde, in IA, xxxix, 208-209.

Atçl, A., The Safavid threat and juristic authority in the Ottoman Empire during the 16th century, in IJMES 49 (2017), 295-314.

112 For manuscript references, see the footnotes in the paper. 
Aykan, Y., A legal concept in motion: The "spreader of corruption" (sā' Qarakhanid to Ottoman jurisprudence, in Islamic law and society 26 (2018), 1-19.

Babayan, K., Mystics, monarchs, and messiahs: Cultural landscapes of early modern Iran, Cambridge, MA 2002.

Baer, M., Honored by the glory of Islam: Conversion and conquest in Ottoman Europe, New York 2008.

Barkey, K., Islam and toleration: Studying the Ottoman imperial model, in International journal of politics, culture, and society 19 (2005), $5^{-19 .}$

Berkey, J.P., The formation of Islam: Religion and society in the Near East, 600-1800, Cambridge 2003 .

Birge, J.K., The Bektashi order of dervishes, Hartford, Cт 1937.

Brockelmann, C., History of the Arabic written tradition, trans. J. Lameer, 2 vols., Leiden 2017.

Burak, G., Faith, law and empire in the Ottoman "age of confessionalization" (fifteenthseventeenth centuries): The case of "renewal of faith," in Mediterranean historical review 28 (2013), 1-23.

Curry, J., The transformation of Muslim mystical thought in the Ottoman Empire: The rise of the Halveti order, 1350-1650, Edinburgh 2010.

De Nicola, B., The Fusțāt al-'Adāla: A unique manuscript on the religious landscape of medieval Anatolia, in A.C.S. Peacock and S.N. Yildiz (eds.), Literature and intellectual life in Islamic Anatolia in the 14th-15th centuries: Historical, social and political perspectives, Würzburg 2015, 49-72.

Dressler, M., Inventing orthodoxy: Competing claims for authority and legitimacy in the Ottoman-Safavid conflict, in H.T. Karateke and M. Reinkowski (eds.), Legitimizing the order: The Ottoman rhetoric of state power, Leiden 2005, 151-173.

Eberhard, E., Osmanische Polemik gegen die Safawiden im 16. Jahrhundert nach arabischen Handschriften, Freiburg 1970.

Ebussuûd, Ma'rûzât, ed. P. Düzenli, Istanbul 2013.

van Ess, J., Der Eine und das Andere: Beobachtungen an islamischen häresiographischen Texten, 2 vols., Berlin 2011.

van Ess, J., The flowering of Muslim theology, trans. J.M. Todd, Cambridge, MA 2006.

Fığlalı, E.R., İbn Sadru'd-Din eş-Şirvânî ve itikâdî mezhepler hakkındaki Türkçe risâlesi, in Ankara Üniversitesi ilahiyat fakültesi dergisi 24 (1981), 249-276.

al-Ghazzī, Najm al-Dīn, Husn al-tanabbuh limā warada fi-l-tashabbuh, ed. N. Ṭālib, Dimashq 2011.

Görke, A. and K. Hirschler (eds.), Manuscript notes as documentary sources, Beirut 2011.

Gratien, C., M. Polczyński and N. Shafir, "Digital frontiers of Ottoman studies," Journal of the Ottoman and Turkish studies association 1 (2014), 37-51.

Griffel, Frank, Apostasy, in $E I^{3}$, i, 131-134. 
Hanefi, Ebu Muhammad Osman, Sapıklarla dinsizlerin çeşitli mezhepleri (el-firaku'lmufterika beyne ehli'z-zeyg ve'z-zandaka), ed. Y. Kutluay, Ankara 1961.

Ḥājji Khalīfa, M. (Kātib Çelebi), Kashf al-z̧unūn 'an asāmi al-kutub wa-l-funūn, 2 vols., Istanbul 1941.

Hodgson, M.G.S., Bāținiyya, in $E I^{2}$, i, 1098-10o.

Hodgson, M.G.S., Bayān b. Samān al-Tamīmī, in $E I^{2}$, i, 1116-1117.

Ibn Ma'ṣūm, Rị̣lat Ibn Mașūm al-Madani aw salwat al-gharīb wa uswat al-arīb, ed. S.H. Shukr, Beirut 1988.

IslamAnatolia: The Islamisation of Anatolia, c. 1100-1500, https://www.islam-anatolia .ac.uk/?page_id=333, Last accessed: 30 June 2018.

Kafadar, C., Between two worlds: The construction of the Ottoman state, Berkeley 1995 .

Karamustafa, A., God's unruly friends: Dervish groups in the Islamic later middle period, 1200-1550, Salt Lake City 1994.

Kaylı, A., A critical study of Birgivi Mehmed Efendi's (d. 981/1573) works and their dissemination in manuscript form, MA Thesis, Boğaziçi University 2010.

Kayserling, M., Richelieu, Buxtorf père et fils, Jacob Roman, in Revue des études juives 8 (1884), 74-95.

Knysh, A.D., "Orthodoxy" and "heresy" in medieval Islam: An essay in reassessment, $M W$ 83 (1993), 48-67.

Krstić, T., A catechizing grand vizier: Lütfi Pasha (d. 1562/63) and the politics of Sunni confession building in the sixteenth-century Ottoman Empire, forthcoming.

Krstić, T., Contested conversions to Islam: Narratives of religious change in the early modern Ottoman Empire, Palo Alto 2011.

Krstić, T., From shahāda to 'aqīda: Conversion to Islam, catechisation, and sunnitisation in sixteenth-century Ottoman Rumeli, in A.C.S. Peacock (ed.), Islamisation: Comparative perspectives from history, Edinburgh 2017, 296-313.

Krstić, T., State and religion: "Sunnitization" and "confessionalism" in Süleyman's time, in P. Fodor (ed.), The battle for Central Europe: The siege of Szigetvár and the death of Süleyman the magnificent's and Nicholas Zrínyi (1566), Leiden, Boston, Budapest 2019, 65-92.

Küpeli, Ö., Osmanlı-Safevi münasebetleri, 1612-1639, Istanbul 2014.

Lawrence, B.B., Shahrastānī on the Indian religions (RS 4), The Hague 1976.

Lewinstein, K., Notes on eastern Hanafite heresiography, in JAOS 114 (1994), 583-598.

Messick, B.M., Sharîa scripts: A historical anthropology, New York 2018.

Mottahedeh, R.P., "Pluralism and Islamic traditions of sectarian divisions," in Z. Hirji (ed.), Diversity and pluralism in Islam: Historical and contemporary discourses amongst Muslims, London 2010, 31-41.

Nūḥ b. Mușțafā, Tercümetü'l-milel ve'n-nihal, Istanbul 1862.

Ocak, A.Y., Osmanlı toplumunda zındıklar ve mülhidler (15.-17. yüzyıllar), 2nd ed., Istanbul 1998. 
Özkılıç, C., Sunnitization through translation: Nuh ibn Mustafa's (1590-166o) Tercüme-i Milel ve Nihal, MA Thesis, İstanbul Şehir University 2015.

Rudolph, U., Al-Māturīdi and the development of Sunni theology in Samarqand, trans. R. Adem, Leiden 2015.

Rycaut, P., The present state of the Ottoman Empire: Sixth edition (1686), ed. J.A. Butler, Tempe, Ariz. 2017.

Sezer, Y., The architecture of bibliophilia: Eighteenth-century Ottoman libraries, $\mathrm{PhD}$ diss., Massachusetts Institute of Technology 2016.

al-Shahrastānī, Muḥammad ibn 'Abd al-Karīm, Livre des religions et des sectes, trans. D. Gimaret and G. Monnot, Paris 1986.

el-Shamsy, A., The social construction of orthodoxy, in T. Winter (ed.), The Cambridge companion to classical Islamic theology, Cambridge 2008, 97-117.

el-Şirvānī, M., Tercümânü'l-ümem, ed. E.R. Fığlalı, in Ankara Üniversitesi ilâhiyatfakültesi dergisi 24 (1981), 277-335.

Sourdel, D., La classification des sectes islamiques dans le 'kitab al-milal' d'al-Šahristānī, in SI 31 (1970), 239-247.

Steinschneider, M., Zur arabischen Literatur, in ZDMG 9 (1855), 837-843.

Tan, M., Geç dönem Hanefî-Mâturîdî firak geleneği bağlamında bir risale: 'el-makâlât fî beyâni ehli'l-bida' ve'd-dalâlât,' in İlahiyat fakültesi dergisi 14 (2009), 181-202.

Tan, M., Hanefî-Mâturîdî firak geleneği bağlamında mezheplerin tasnifi meselesi, in Ankara Üniversitesi ilahiyat fakültesi dergisi 49 (2008), 121-152.

Terzioğlu, D., How to conceptualize Ottoman Sunnitization: A historiographical discussion, in Turcica 44 (2013), 301-338.

Terzioğlu, D., Where 'ilm-i ḩăl meets catechism: Islamic manuals of religious instruction in the Ottoman Empire in the age of confessionalization, in Past and present 220 (2013), 79-115.

Al-Tikriti, N., Kalam in the service of state: Apostasy and the defining of Ottoman Islamic identity, in H.T. Karateke and M. Reinkowski (eds.), Legitimizing the order: The Ottoman rhetoric of state power, Leiden 2005, 131-149.

Tucker, E., Nadir Shah and the Ja'fari madhhab reconsidered, in Iranian studies 27 (1994), 163-179.

Üstün, İ.S., Heresy and legitimacy in the Ottoman Empire in the sixteenth century, PhD diss., University of Manchester, 1991.

Wasserstrom, S., Islamicate history of religions?, in History of religions 27 (1988), 405411.

Yaşaroğlu, M., Kâmil. Nûh b. Mustafa, in IA, xxxiii, 230-231.

Yıldırım, R., Sunni orthodox vs Shi'ite heterodox?: A reappraisal of Islamic piety in medieval Anatolia, in A.C.S. Peacock, B. De Nicola and S.N. Yıldız (eds.), Islam and Christianity in medieval Anatolia, London 2016, 287-307.

Yilmaz, H., İran'dan Sünni kaçısı ve Osmanlı devleti'nde Safevî karşıtı propagandanın 
yaygınlaşması: Hüseyin b. Abddulah el-Şirvânî’nin mesiyanik çağrısı, in Ö.M. Alper and M. Arıcı (eds.), Osmanlida ilim ve fikir dünyası: İstanbul'un fethinden Süleymaniye medreselerinin kuruluşuna kadar, Istanbul 2015, 299-310.

Yilmaz, H., Caliphate redefined: The mystical turn in Ottoman political thought. Princeton, NJ 2018.

Yunus E., Yûnus Emre dîvânı: Tenkitli metin, ed. M. Tatcı, 2 vols., Istanbul 2008.

Zilfi, M., The politics of piety: The Ottoman ulema in the postclassical age (1600-1800), Minneapolis, 1988. 